\title{
Evaluation of Ischemic Stroke and Risk Factors of Atrial Fibrillation in Patients with Obstructive Sleep Apnea Syndrome
}

\author{
Obstrüktif Uyku Apnesi Olan Hastalarda İskemik İnme ve Atriyal Fibrilasyon Risk \\ Faktörlerinin Değerlendirilmesi
}

\author{
(1) Yasemin Dinç, (1) Aylin Bican Demir \\ Uludag University Faculty of Medicine, Department of Neurology, Bursa, Turkey
}

\begin{abstract}
Objective: Obstructive sleep apnea syndrome (OSAS), a sleep-related breathing disorder, is characterized by apnea and hypoapnea. In patients with OSAS, ischemic stroke may have various causes such as large-vessel atherosclerosis and cardioembolism. OSAS is one of the risk factors of atherosclerosis, and it is thought to increase the risk of ischemic stroke by triggering atherosclerosis. Many studies have shown the relationship between OSAS and cardioembolic stroke. Ischemic stroke is a heterogeneous group of diseases caused by many complex mechanisms and may show ethnic and racial differences. This study aimed to determine the etiology and risk factors of ischemic stroke in the patient group diagnosed with OSAS in our population.

Materials and Methods: A total of 343 patients were retrospectively screened to determine the prevalence and risk factors of ischemic stroke in patients with obstructive sleep apnea in the sleep laboratory of the Department of Neurology, Faculty of Medicine, Uludag University, between 2015 and 2020.

Results: The study included $38(11 \%)$ patients who were diagnosed with ischemic stroke. When patients with and without ischemic stroke were compared according to clinical, demographic, radiological, and polysomnographic data, a significant relationship was found in age, atrial fibrillation (AF), heart failure, hypertension, coronary artery disease, diabetes mellitus, smoking, and non-rapid eye movement 1 . According to the binary logistic regression analysis, the variable most significantly related with ischemic stroke was AF. A significant relationship was found between OSAS severity and AF.

Conclusion: OSAS is a treatable sleep disorder that causes cardiovascular morbidity. OSAS is an important risk factor for the development and recurrence of AF. In this study, AF is the most important variable related to ischemic stroke in patients with OSAS, and it is associated with the severity of OSAS. Thus, patients with OSAS must be evaluated for AF to prevent ischemic stroke.
\end{abstract}

Keywords: Obstructive sleep apnea, ischemic stroke, atrial fibrillation, apnea-hypopnea index

$\ddot{O} \mathbf{z}$

Amaç: Uykuda solunum bozukluklarından biri olan obstrüktif uyku apnesi sendromu (OUAS), solunum için çaba harcanmasına rağmen apne ve hipoapne ile karakterizedir. OUAS olan hastalarda iskemik inme hem büyük arter aterosklerozuna bağ li, hem de kardiyoembolizm gibi etiyolojiler ile meydana gelebilir. OUAS ateroskleroza neden olan risk faktörlerinden biri olarak tanımlanmakta olup OUAS'nin aterosklerozu tetikleyerek iskemik inme riskini artırdı ̆̆ düşünülmektedir. Birçok çalışmada ise OUAS ile kardiyoembolik inme arasındaki ilişki gösterilmiştir. İskemik inme birçok karmaşık mekanizmanın sebep olduğu heterojen bir hastalık grubudur, ayrıca etnik ve ırksal farklılıklar da gösterebilir. Bu çalışmanın amacı kendi popülasyonumuzda OUAS tanısı konulan hasta grubunda iskemik inme etiyolojisi ve risk faktörlerinin saptanmasıdır.

Gereç ve Yöntem: Bu çalışmaya Uludağ Üniversitesi Tıp Fakültesi Nöroloji Anabilim Dalı uyku laboratuvarında 2015 -2020 tarihleri arasında obstrüktif uyku apne tanısı konulan hastaların iskemik inme prevalansını ve iskemik inme risk faktörlerini belirlemek için 343 hasta retrospektif taranarak dahil edildi.

Bulgular: Çalışmaya dahil edilen 38 (\%11) hastanın iskemik inme tanısı mevcuttu. İskemik inmesi olan ve olmayan hastalar klinik, demografik, radyolojik ve polisomnografik verilerine göre kıyaslandığında, yaş, atriyal fibrilasyon (AF), kalp yetmezliği, hipertansiyon varlığı, koroner arter hastalığı, diabetes mellitus ve sigara ve non-REM 1 ile istatistiksel olarak anlamlı ilişki saptandı. Binary logistik regresyon analizi sonuçlarına göre iskemik inme ile en anlamlı ilişkisi olan değişkenin AF olduğu saptandı. OUAS şiddeti ve AF varlığı arasındaki ilişki analiz edildiğinde istatistiksel olarak anlamlı saptandı.

Sonuç: OUAS kardivasküler morbiditeye neden olan tedavi edilebilir bir uyku bozukluğudur. OUAS AF gelişmesinde ve tekrarlamasında önemli bir risk faktörüdür. Ayrıca OUAS tedavi edilmediğinde AF tedavisinde yetersizliğe sebep olabilir. Biz OUAS tanısı alan hastalarda iskemik inme ile ilgili en önemli değişkenin AF olduğunu ve AF'nin OUAS şiddeti ile ilişkili olduğunu bulduk. OUAS tanısı konulan hastalarda iskemik inmeyi önlemek için hastaların AF açısından değerlendirilmesini öneriyoruz. Kendi popülasyonumuzda yapılacak prospektif çalışmalarla daha kesin bilgilere ulaşılabilir.

Anahtar Kelimeler: Obstrüktif uyku apnesi, iskemik inme, atriyal fibrilasyon, apne-hipopne indeksi

Address for Correspondence/ Yazışma Adresi: Yasemin Dinç MD, Uludag University Faculty of Medicine, Department of Neurology, Bursa, Turkey Phone: +90 5301790512 E-mail: yaseminden87@ hotmail.com ORCID: orcid.org/0000-0003-0342-5939

Received/Geliş Tarihi: 05.07.2021 Accepted/Kabul Tarihi: 25.07.2021

${ }^{\circ}$ Copyright 2021 by Turkish Neurological Society

Turkish Journal of Neurology published by Galenos Publishing House. 


\section{Introduction}

Obstructive sleep apnea syndrome (OSAS), a sleep-related breathing disorder, is characterized by apnea and hypoapnea despite efforts to breathe. The incidence of OSAS, which is associated with excessive daytime sleepiness, is $2-5 \%$ in women and $3-7 \%$ in men. In the general population, the prevalence of asymptomatic OSAS is $9 \%$ in women and $24 \%$ in men (1). OSAS is also seen in $>50 \%(44-93 \%)$ of patients with acute ischemic stroke and $>60 \%$ of patients with acute coronary events. Studies have shown that OSAS is an independent risk factor for stroke and cardiovascular mortality (2). The incidence of ischemic stroke is 2-3 times higher in patients with OSAS than in the general population. Moreover, an increase in OSAS severity intensifies the risk of ischemic stroke. In patients with OSAS, ischemic stroke may occur because of large-artery atherosclerosis and etiologies such as cardioembolism (3). Obstructive apneas trigger intermittent hypoxia and hypercapnia, resulting in autonomic and hemodynamic dysfunctions. At the end of apnea, systemic blood pressure rises, and the heart rate and heart output increase. The continuity of these events is a risk factor for atherosclerosis (4). OSAS is one of the risk factors of atherosclerosis, and it is thought to increase the risk of ischemic stroke by triggering atherosclerosis (5). Many studies have shown the relationship between OSAS and cardiovascular diseases including arrhythmias, coronary artery disease, left ventricular dysfunction, and pulmonary and systemic hypertension (HT).

Atrial fibrillation (AF) is the most common arrhythmia, and the evidence for the relationship between OSAS and AF has been accumulating in recent years $(6,7)$. Ischemic stroke is a heterogeneous group of diseases caused by various complex mechanisms and may be accompanied by ethnic and racial differences (8). This study aimed to determine the etiology and risk factors of ischemic stroke in patients with OSAS.

\section{Materials and Methods}

This study was performed to determine the prevalence of ischemic stroke and risk factors of ischemic stroke in patients diagnosed with OSAS in the sleep laboratory of the Department of Neurology, Faculty of Medicine, Uludag University. Between 2015 and 2020, 343 patients with OSAS were retrospectively screened and included.

The inclusion criteria for the study were as follows: diagnosis of OSAS syndrome after being examined in the sleep laboratory of the Department of Neurology, Uludag University Medical Faculty, regular follow-ups in the neurology sleep outpatient clinic after the diagnosis of OSAS, cranial magnetic resonance imaging (MRI), electrocardiography (ECG), and complete blood count, low-density lipoprotein (LDL) level, serum creatinine level, and serum Hba1c level.

The study was approved by the Clinical Research Ethics Committee of Uludag University Faculty of Medicine (dated 09.03.2021 and numbered 2011-KAEK-26/211, decision no: 2021-5/12). Patient consent was not required, given the retrospective study design.

Patients who were admitted to the neurology sleep outpatient clinic due to sleep-related breathing disorders were evaluated.
Cranial MRI, ECG, whole blood, LDL, and creatinine serum levels were examined in patients with a history of ischemic stroke who underwent polysomnography for suspected OSAS.

For polysomnography, three electroencephalogram channels [according to the international 10-20 insertion system (F3-A2, C3-A2, O1-A2)]; two electrooculogram channels; thermal sensors on the chin, right and left tibialis anterior muscles, and oronasal region; and nasal pressure sensors were used. Body position, thoracic and abdominal respiratory movements, ECG, pulse, respiratory sounds, and $\mathrm{O}_{2}$ saturation were recorded, and synchronous video recording was performed. Polysomnographic recording and evaluation of all patients were performed by an accredited and certified sleep specialist in accordance with the American Academy of Sleep Medicine (AASM)-International Classification of Sleep Disorders 3 -2014 diagnostic criteria. Patients' sleep was scored in 30-s epochs, and alertness, rapid eye movement (REM), nonREM 1 (N1), non-staged as REM 2 (N2), and non-REM 3 (N3) periods were evaluated. Abnormal breathing events associated with sleep were graded according to the scoring guidelines of the AASM. According to AASM scoring system, complete or near-complete cessation of breathing lasting a minimum of 10 $\mathrm{s}$, which was determined by oronasal thermistor measurement in respiratory parameters with $\geq 90 \%$ reduction in peak signal relative to baseline activity, was classified as obstructive-type apnea if accompanied by thoracic and or abdominal breathing and as central apnea in the absence of abdominal or thoracic respiratory efforts. An obstructive-type hypopnea occurred when there was at least $10 \mathrm{~s}$ of decrease $>30 \%$ from the baseline in nasal pressure signal accompanied by $\geq 3 \%$ desaturation and accompanied by thoracic and/or abdominal respiratory effort. Oxygen desaturation index (ODI) $\geq 3 \%$ (ODI $\geq 3 \%$ number $x$ 60/total sleep time): The time elapsed below the specified threshold value was also stated in the report as a percentage (9).

OSAS severity was classified according to the apnea-hypopnea index (AHI). AHI between 5 and 15 was classified as "mild OSAS," between 15 and 30 as "moderate OSAS," and >30 as "severe OSAS" (10).

\section{Statistical Analysis}

Clinical, demographic, polysomnographic, and radiological data of patients with OSAS with and without ischemic stroke were compared. Analyses were made using the IBM SPSS Statistics 23 package program. Normally distributed continuous variables were presented as number, mean, and standard deviations. Independent samples were evaluated with the t-test. The median value and $25^{\text {th }}$ and $75^{\text {th }}$ percentiles were calculated for variables without normal distribution and analyzed with the Mann-Whitney $\mathrm{U}$ test. Categorical variables are presented as percentages and evaluated with the chi-square test. Variables that were evaluated as significant ischemic stroke risk factors of patients with OSAS were analyzed by backward-stepwise binary logistic regression. A $\mathrm{p}$ value $<0.05$ was considered significant.

\section{Results}

A total of 343 patients, including 108 (31\%) women and 235 $(69 \%)$ men, were included in this study. The mean ages of the 
female and male participants were $62.41 \pm 9.56$ and $54.85 \pm 12.34$, respectively. A significant difference was found between the mean ages $(\mathrm{p}<0.001)$. The $38(11 \%)$ patients included in the study had a history of ischemic stroke. The etiologies of ischemic stroke were large-artery atherosclerosis $(n=7)$, cardioembolism $(n=22)$, small-vessel occlusion $(n=4)$, other causes $(n=1)$, and ischemic stroke of unknown cause $(n=1)$. When patients with OSAS with and without ischemic stroke were compared according to clinical, demographic, radiological, and polysomnographic data, significant differences were found in age $(\mathrm{p}=0.005), \operatorname{AF}(\mathrm{p}<0.001)$, heart failure $(\mathrm{HF})(\mathrm{p}<0.001)$, HT $(\mathrm{p}<0.001)$, coronary artery disease $(p<0.001)$, diabetes mellitus $(D M)(p<0.001)$, smoking $(\mathrm{p}=0.001)$, and $\mathrm{N} 1(\mathrm{p}=0.044)$, while no differences were found in gender, LDL, hemogram, Hbalc, creatinine, total sleep time (TST), N2, N3, REM, minimum oxygen saturation (MOS), mean oxygen concentration, sleep efficiency, AHI, and ODI (Table 1).

In the backward-stepwise binary logistic regression analysis of significant variables related to ischemic stroke risk factors, the most significant variables were HT $(\mathrm{p}=0.018)$, AF $(\mathrm{p}<0.001)$, and smoking $(\mathrm{p}=0.012)$ (Table 2). According to the results of the binary logistic regression analysis, AF was the most significant variable in patients with OSAS. Thus, AF risk factors in patients with OSAS were also analyzed.
When patients with OSAS with and without AF were compared according to clinical, demographic, radiological, and polysomnographic data, significant differences were observed in age $(\mathrm{p}<0.001)$, hemoglobin $(\mathrm{p}=0.002), \mathrm{N} 1 \quad(\mathrm{p}=0.018), \mathrm{N} 3$ $(p=0.023)$, MOS $(p=0.009)$, sleep efficiency $(p=0.008)$, AHI $(\mathrm{p}=0.009)$, ODI $(\mathrm{p}=0.031)$, coronary artery disease $(\mathrm{p}=0.0000)$, HT ( $\mathrm{p}=0.002)$, and HF $(\mathrm{p}<0.001)$, while no differences were noted in gender, smoking, LDL, Hba1c, creatinine, TUS, N2, REM, MOS, and DM (Table 3).

In the backward-stepwise binary logistic regression analysis of significant variables related to patients with AF, the most significant variables were $\operatorname{HF}(\mathrm{p}<0.001)$, coronary artery disease $(\mathrm{p}=0.001)$, age $(\mathrm{p}=0.010)$, and AHI $(\mathrm{p}=0.008)$ (Table 4).

As regards OSAS severity, $128(37.4 \%)$ patients had mild OSAS, $124(36.1 \%)$ had moderate OSAS, and 91 (26.5\%) had severe OSAS. A significant relationship was found between the OSAS severity and presence of AF ( $\mathrm{p}=0.017)$ (Table 5).

\section{Discussion}

OSAS is directly related to risk factors of ischemic stroke such as obesity, increased insulin resistance, HT and metabolic syndrome, hypercoagulability, and coronary artery disease and is an independent risk factor as it plays a role in the development

Table 1. Evaluation of clinical demographic and polysomnographic data in patients with ischemic stroke

\begin{tabular}{|c|c|c|c|}
\hline & $\begin{array}{l}\text { Patients with ischemic stroke with } \\
\text { OSAS }(n=38)\end{array}$ & $\begin{array}{l}\text { Patients without ischemic stroke } \\
\text { with OSAS }(n=305)\end{array}$ & $\mathrm{p}$ value \\
\hline Age $^{*}$ & $62.60 \pm 11.99$ & $56.62 \pm 11.95$ & 0.004 \\
\hline Gender (male)** & $29(76 \%)$ & $206(67 \%)$ & 0.361 \\
\hline Being a smoker*** & $21(55 \%)$ & $86(28 \%)$ & 0.001 \\
\hline Hemoglobin $(\mathrm{g} / \mathrm{dl})^{*}$ & $13.23 \pm 2.07$ & $12.81 \pm 1.62$ & 0.085 \\
\hline $\mathrm{LDL}(\mathrm{mg} / \mathrm{dl})^{*}$ & $118.86 \pm 32.99$ & $121.33 \pm 40.4$ & 0.141 \\
\hline $\mathrm{Hba1c}(\mathrm{mmol} / \mathrm{mol})^{*}$ & $6.21 \pm 1.29$ & $6.09 \pm 1.24$ & 0.929 \\
\hline Creatinine $(\mathrm{mg} / \mathrm{dl})^{*}$ & $1.24 \pm 1.53$ & $0.9 \pm 0.64$ & 0.069 \\
\hline Hypertension* & $30(80 \%)$ & $134(\%)$ & $<0.001$ \\
\hline Diabetes mellitus* & $18(\%)$ & $83(\%)$ & 0.022 \\
\hline Atrial fibrillation* & $20(\%)$ & $23(\%)$ & $<0.001$ \\
\hline Heart failure* & $15(\%)$ & $14(\%)$ & $<0.001$ \\
\hline Coronary artery disease & $21(\%)$ & $47(\%)$ & $<0.001$ \\
\hline TST $^{*}$ & $325.85 \pm 61.42$ & $344.76 \pm 59.82$ & 0.119 \\
\hline $\mathrm{N} 1^{*}$ & $7.05 \pm 5.08$ & $5.41 \pm 3.71$ & 0.044 \\
\hline $\mathrm{N} 2 *$ & $56.53 \pm 13.17$ & $55.63 \pm 13.22$ & 0.927 \\
\hline N3* & $19.88 \pm 12.00$ & $22.58 \pm 10.67$ & 0.078 \\
\hline $\mathrm{REM}^{*}$ & $16.51 \pm 8.40$ & $16.10 \pm 8.08$ & 0.686 \\
\hline Sleep efficiency & $84.22 \pm 9.61$ & $85.43 \pm 10.14$ & 0.251 \\
\hline Minimum oxygen saturation* & $78.25 \pm 11.50$ & $80.90 \pm 10.04$ & 0.077 \\
\hline Average oxygen saturation* & $93.81 \pm 2.16$ & $93.40 \pm 6.32$ & 0.491 \\
\hline $\mathrm{AHI}^{*}$ & $30.27 \pm 18.32$ & $25.40 \pm 19.97$ & 0.061 \\
\hline ODI* & $25.46 \pm 21.154$ & $20.53 \pm 21.72$ & 0.121 \\
\hline
\end{tabular}


Table 2. Evaluation of significant variables related to ischemic stroke in patients with obstructive sleep apnea syndrome using backward-wald logistic regression

$\begin{array}{lcccc} & & & & \text { 95\% confidence interval } \\ & \text { p value } & \text { Odds ratio } & \text { Lower } & \text { Upper } \\ \text { Smoking } & 0.012 & 2.83 & 1.25 & 6.43 \\ \text { Hypertension } & 0.018 & 2.93 & 1.20 & 7.17 \\ \text { Atrial fibrillation } & <0.001 & 7.11 & 2.58 & 19.52 \\ \text { Heart failure } & 0.054 & 2.90 & 0.98 & 9.05 \\ \begin{array}{l}\text { Variables evaluated in STEP 1: Age, smoking, hypertension, diabetes mellitus, atrial fibrillation, heart failure, coronary artery disease, non-REM 1, Significance of the model: } \\ \text { p }<0.001\end{array}\end{array}$

Table 3. Comparison of clinical, demographic, and polysomnographic findings in patients with atrial fibrillation

\begin{tabular}{|c|c|c|c|}
\hline & OSA patients with AF $(n=43)$ & OSA patients without AF $(n=300)$ & $\mathrm{p}$ value \\
\hline Age* & $67.27 \pm 10.13$ & $55.93 \pm 11.61$ & $<0.001$ \\
\hline Gender (male)** & $29(\%)$ & $201(\%)$ & 0.994 \\
\hline Being a smoker** & $15(\%)$ & $92(\%)$ & 0.789 \\
\hline Hemoglobin (g/dl)* & $13.01(\%) \pm 1.7$ & $13.94 \pm 1.72$ & 0.002 \\
\hline $\mathrm{LDL}(\mathrm{mg} / \mathrm{dl})^{*}$ & $123.67 \pm 35.23$ & $127.11 \pm 38.59$ & 0.574 \\
\hline $\mathrm{Hba1c}(\mathrm{mmol} / \mathrm{mol})^{*}$ & $6.06 \pm 1.40$ & $6.11 \pm 1.22$ & 0.351 \\
\hline Creatinine $(\mathrm{mg} / \mathrm{dl})^{*}$ & $1.15 \pm 1.44$ & $0.92 \pm 0.65$ & 0.153 \\
\hline Hypertension* & $31(\%)$ & $132(\%)$ & 0.002 \\
\hline Diabetus mellitus* & $15(\%)$ & $85(\%)$ & 0.552 \\
\hline Ischemic stroke* & $20(\%)$ & $18(\%)$ & $<0.001$ \\
\hline Heart failure* & $23(\%)$ & $6(\%)$ & $<0.001$ \\
\hline Coronary artery disease & $31(\%)$ & $37(\%)$ & $<0.001$ \\
\hline TST* & $328.11 \pm 61.23$ & $344.61 \pm 60.01$ & 0.118 \\
\hline $\mathrm{N} 1 *$ & $7.38 \pm 5.7$ & $5.35 \pm 3.49$ & 0.018 \\
\hline $\mathrm{N} 2 *$ & $58.68 \pm 14.93$ & $55.28 \pm 12.93$ & 0.210 \\
\hline N3* & $18.97 \pm 12.03$ & $22.77 \pm 10.61$ & 0.023 \\
\hline REM $^{*}$ & $14.14 \pm 7.85$ & $16.35 \pm 8.13$ & 0.148 \\
\hline Sleep efficiency & $82.86 \pm 7.86$ & $85.64 \pm 10.33$ & 0.008 \\
\hline Minimum oxygen saturation* & $77.04 \pm 11.35$ & $81.10 \pm 9.98$ & 0.009 \\
\hline Average oxygen saturation* & $93.26 \pm 2.67$ & $93.44 \pm 6.35$ & 0.104 \\
\hline AHI* & $33.30 \pm 23.76$ & $24.96 \pm 18.76$ & 0.009 \\
\hline ODI* & $27.55 \pm 23.08$ & $20.25 \pm 21.33$ & 0.031 \\
\hline
\end{tabular}

of these processes (11). A direct relationship between OSAS and ischemic stroke showed a strong correlation with ischemic stroke risk factors, stroke incidence, and AHI, and studies have reported a high frequency of OSAS in patients with stroke (12). In patients with OSAS, it is thought that the release of proinflammatory cytokines, increase in free oxygen radicals, endothelial dysfunction, activation of the sympathetic nervous system, and HT increase the risk of ischemic stroke (13). In this study, the prevalence of ischemic stroke in patients with OSAS was $11 \%$. This rate was between $12.5 \%$ and $23 \%$ in previous studies $(14,15,16)$. The findings of our study are similar to the literature. The risk factors most associated with ischemic stroke in patients with OSAS were HT $(\mathrm{p}<0.018)$, AF $(\mathrm{p}<0.001)$, and smoking $(\mathrm{p}=0.012)$. The most significant variable in patients with OSAS was AF.

Systemic HT accompanies OSAS in $30-60 \%$ of the patients $(17,18,19)$. Studies have found that HT increases the risk of ischemic stroke and the severity of ischemic stroke in patients with OSAS (20). OSAS is an independent risk factor for stroke even 
Table 4. Evaluation of significant variables associated with atrial fibrillation in patients with obstructive sleep apnea syndrome using backward-stepwise logistic regression

\begin{tabular}{lllll} 
& p value & Odds ratio & \multicolumn{2}{c}{ 95\% confidence interval } \\
Age & 0.010 & 1.057 & 1.013 & 1.103 \\
Heart failure & 0.000 & 22.58 & 7.022 & 72.668 \\
Coronary artery disease & 0.001 & 4.96 & 1.98 & 12.42 \\
AHI & 0.008 & 1.025 & 1.006 & 1.044 \\
$\begin{array}{l}\text { Variables evaluated in STEP 1: Age, hypertension, heart failure, coronary artery disease, non-REM 1, non-REM 3, sleep efficiency, minimum oxygen concentration, AHI, } \\
\text { and ODI. Significance of the model: p<0.001. AHI: Apnea-hypoapnea index, ODI: Oxygen desaturation index }\end{array}$ \\
\hline
\end{tabular}

Table 5. Evaluation of the relationship between obstructive sleep apnea syndrome severity and atrial fibrillation and ischemic stroke

\begin{tabular}{|c|c|c|c|c|}
\hline & Mild OSAS $n=128$ & Moderate OSAS $n=124$ & Severe OSAS $n=91$ & $\mathrm{p}$ value \\
\hline Patients with atrial fibrillation & $12(9.3 \%)$ & $12(9.7 \%)$ & $19(20.8)$ & 0.017 \\
\hline Patients with ischemic stroke & $11(8.6)$ & $12(9.7 \%)$ & $15(16.4)$ & 0.079 \\
\hline
\end{tabular}

when other risk factors such as HT, DM, hyperlipidemia, and AF are controlled (21). Especially, in older patients, severe OSAS (AHI $\geq 30$ ) causes an increased risk of ischemic stroke (22).

In our study, the severity of OSAS and presence of ischemic stroke were substantially unrelated, while the severity of OSAS and presence of AF were significantly related. This may be attributed to the early evaluation of patients with OSAS in terms of arrhythmia and early anticoagulation. Studies on the prevalence of AF in patients with OSAS reported $10.4-28.8 \%(23,24)$. In our study, the rate was $13 \%$, which agreed with the literature.

The relationship between OSAS and AF is complex and involves various metabolic, inflammatory, autonomic, and neurohumoral factors (25). AF is associated with HT, atherosclerotic heart disease, congestive HF, heart valve diseases, and obesity (7). The evidence of the relationship between OSAS and AF has been increasing in recent years. The incidence of OSAS in patients with AF varies between $32 \%$ and $49 \%$. Epidemiological studies have found that sleep apnea is a risk factor of new-onset AF. Evidence shows that OSAS treatment with continuous positive airway pressure (CPAP) reduces the frequency of AF. Several pathophysiological mechanisms are associated with AF and sleep apnea.

OSAS is characterized by recurrent episodes of nocturnal hypoxemia. Nocturnal intermittent hypoxemia causes mitochondrial dysfunction by affecting cytochrome oxidase and causes oxidative stress (26,27). Hypoxemic episodes induce transcription factors such as nuclear factor kappa-B, which leads to increased production of inflammatory cytokines such as tumor necrosis factor- $\alpha$ and interleukin-6. These cytokines cause endothelial dysfunction, insulin resistance, hypercoagulation, and myocardial dysfunction with the increase of oxidative stress $(28,29,30,31)$. Hypoxemia may affect cardiac arrhythmias even without OSAS. This hypothesis is supported by increased rates of cardiac arrhythmias among patients with chronic obstructive pulmonary disease with nocturnal hypoxemia without sleep apnea (32).
Autonomic dysfunction seen in OSAS contributes to the pathogenesis of AF. Increases in parasympathetic and sympathetic tones are known to trigger AF (33). Afferent inputs from stretch receptors, which are mechanoreceptors in the lung tissue, during normal sleep inhibit paroxysmal parasympathetic discharges that occur during REM sleep $(34,35)$. These receptors are activated by lung expansion during normal ventilation. However, this response is reduced in patients with apnea due to pauses in breathing. Paroxysmal parasympathetic discharges lead to marked paroxysmal bradycardia, and bradycardia is also associated with a reduction in the atrial refractory period. The decrease in the atrial refractory period triggers rapid electrical firing from the atrial tissue adjacent to the pulmonary vein and thus leads to $\operatorname{AF}(33,36,37)$. Hypoxemia and hypercapnia associated with apnea episodes induce chronically increased sympathetic activity (38). High sympathetic activity causes focal discharges from pulmonary veins that have high concentrations of adrenergic and vagal innervation (39). OSAS is also associated with sudden and frequent changes in intrathoracic pressures that are conducted into the atrium and cause atrial distension. Repetitive yawning may predispose to the development of AF by causing atrial enlargement and structural changes in the vicinity of the pulmonary vein $(33,34,35)$. In our study, AF was the risk factor most associated with ischemic stroke in patients with OSAS. CPAP can reduce the frequency of AF by modifying the activation of the sympathetic system that triggers AF, hypoxemia, systemic inflammation, cardiac dysfunction, and HT. Current evidence supports the role of effective OSAS treatment in reducing the risk of AF recurrence (40).

\section{Conclusion}

OSAS is a treatable sleep disorder that causes cardiovascular morbidity. OSAS is a strong risk factor for AF development and its recurrence; if untreated, OSAS is a strong risk factor of insufficient $\mathrm{AF}$ treatment. In this study, the most important variable related 
to ischemic stroke in patients with OSAS was AF, which was associated with OSAS severity. Thus, patients with OSAS must be evaluated to prevent ischemic stroke. This study is limited by its retrospective design, as patients were included according to their medical records. We suggest performing prospective studies to evaluate the long-term clinical characteristics and treatments of the patients.

\section{Ethics}

Ethics Committee Approval: The study was approved by the Clinical Research Ethics Committee of Uludag University Faculty of Medicine (dated 09.03.2021 and numbered 2011-KAEK26/211, decision no: 2021-5/12).

Informed Consent: Retrospective study.

Peer-review: Externally peer-reviewed.

\section{Authorship Contributions}

Surgical and Medical Practices: Y.D., A.B.D., Concept: Y.D., A.B.D., Design: Y.D., A.B.D., Data Collection or Processing: Y.D., A.B.D., Analysis or Interpretation: Y.D., A.B.D., Literature Search: Y.D., A.B.D., Writing: Y.D., A.B.D.

Conflict of Interest: No conflict of interest was declared by the authors.

Financial Disclosure: The authors declared that this study received no financial support.

\section{References}

1. Epstein LJ, Kristo D, Strollo PJ Jr, et al. Clinical guideline for the evaluation, management and long-term care of obstructive sleep apnea in adults. J Clin Sleep Med 2009;5:263-276.

2. Punjabi NM. The epidemiology of adult obstructive sleep apnea. Proc Am Thorac Soc 2008;5:136-143.

3. Sarıdaş F, Demir AB, Zarifoğlu M, Bora İ. The role of obstructive sleep apnea syndrome as a cause of stroke. J Turk Sleep Med 2015;3:69-71.

4. Loke YK, Brown JW, Kwok CS, Niruban A, Myint PK. Association of obstructive sleep apnea with risk of serious cardiovascular events: a systematic review and meta-analysis. Circ Cardiovasc Qual Outcomes 2012;5:720-728.

5. Lévy P, Pépin JL, Arnaud C, et al. Obstructive sleep apnea and atherosclerosis. Prog Cardiovasc Dis 2009;51:400-410.

6. Baranchuk A, Simpson CS, Redfearn DP, Fitzpatrick M. It's time to wake up! Sleep apnea and cardiac arrhythmias. Europace 2008;10:666-667.

7. Gami AS, Friedman PA, Chung MK, Caples SM, Somers VK. Therapy Insight: interactions between atrial fibrillation and obstructive sleep apnea. Nat Clin Pract Cardiovasc Med 2005;2:145-149.

8. Dinç Y, Bakar M, Hakyemez B. Causes of ischemic stroke in patients with atrial fibrillation. Turk J Neurol 2020;26:311-315.

9. Berry RB, Albertario CL, Harding SM, et al. The AASM Manual for the Scoring of Sleep and Associated Events, Rules, Terminology and Technical Specifications, Version 2,5 www.aasmnet.org, Darien, IL: American Academy of Sleep Medicine; 2018.

10. Iber C, Ancoli-Israel S, Chesson AL, Quan SF. The AASM manual for the scoring of sleep and associated events: rules, terminology and technical specifications: American Academy of Sleep Medicine Westchester, IL; 2007.

11. Culebras A. Cerebrovascular disease and sleep. Curr Neurol Neurosci Rep 2004;4:164-169.

12. Medeiros CA, de Bruin VM, Andrade GM, et al. Obstructive sleep apnea and biomarkers of inflammation in ischemic stroke. Acta Neurol Scand 2012;126:17-22

13. Cereda C, Lavie L, Bassetti CL. Sleep disorders in neurology. New York, NY: Nova Science Publishers, 2012.

14. Bassetti C, Aldrich MS, Chervin RD, Quint D. Sleep apnea in patients with transient ischemic attack and stroke: a prospective study of 59 patients. Neurology 1996;47:1167-1173.
15. Bassetti C, Aldrich MS. Sleep apnea in acute cerebrovascular diseases: final report on 128 patients. Sleep 1999;22:217-223.

16. Dyken ME, Somers VK, Yamada T, Ren ZY, Zimmerman MB. Investigating the relationship between stroke and obstructive sleep apnea. Stroke 1996;27:401-407.

17. Phillips B. Sleep-disordered breathing and cardiovascular disease. Sleep Med Rev 2005;9:131-140

18. Parish JM, Somers VK. Obstructive sleep apnea and cardiovascular disease. Mayo Clin Proc 2004;79:1036-1046.

19. Roux F, D'Ambrosio C, Mohsenin V. Sleep-related breathing disorders and cardiovascular disease. Am J Med 2000;108:396-402.

20. Mohsenin V. Sleep-related breathing disorders and risk of stroke. Stroke 2001;32:1271-1278.

21. Yaggi HK, Concato J, Kernan WN, et al. Obstructive sleep apnea as a risk factor for stroke and death. N Engl J Med 2005;353:2034-2041.

22. Munoz R, Duran-Cantolla J, Martínez-Vila E, et al. Severe sleep apnea and risk of ischemic stroke in the elderly. Stroke 2006;37:2317-2321.

23. Gami AS, Pressman G, Caples SM, et al. Association of atrial fibrillation and obstructive sleep apnea. Circulation 2004;110:364-367.

24. Dhakal SS, Neupane A, Bhattarai M, Karki DB. Prevalence of Atrial Fibrillation in Obstructive Sleep Apnea Patients in a Tertiary Care Center JNMA J Nepal Med Assoc 2020;58:80-83.

25. Abumuamar AM, Mollayeva T, Sandor P, et al. Efficacy of continuous positive airway pressure treatment in patients with cardiac arrhythmia and obstructive sleep apnea: what is the evidence? Clin Med Insights Ther 2017;9:1-10

26. McGown AD, Makker H, Elwell C, et al. Measurement of changes in cytochrome oxidase redox state during obstructive sleep apnea using nearinfrared spectroscopy. Sleep 2003;26:710-716.

27. Peng Y, Yuan G, Overholt JL, Kumar GK, Prabhakar NR. Systemic and cellular responses to intermittent hypoxia: evidence for oxidative stress and mitochondrial dysfunction. Adv Exp Med Biol 2003;536:559-564.

28. Endothelial dysfunction in adults with obstructive sleep apnea. Adv Cardiol 2011;46:139-170.

29. Faulhaber M, Gatterer H, Haider T, et al. Heart rate and blood pressure responses during hypoxic cycles of a 3 -week intermittent hypoxia breathing program in patients at risk for or with mild COPD. Int J Chron Obstruct Pulmon Dis 2015;10:339-345.

30. Prabhakar NR. Sleep apneas: an oxidative stress? Am J Respir Crit Care Med 2002; 165:859-860

31. Lévy P, Pépin JL, Arnaud C, et al. Intermittent hypoxia and sleep-disordered breathing: current concepts and perspectives. Eur Respir J 2008;32:10821095

32. Zipes DP, Camm AJ, Borggrefe M, et al. ACC/AHA/ESC 2006 guidelines for management of patients with ventricular arrhythmias and the prevention of sudden cardiac death: a report of the American College of Cardiology/ American Heart Association Task Force and the European Society of Cardiology Committee for Practice Guidelines (Writing Committee to Develop Guidelines for Management of Patients With Ventricular Arrhythmias and the Prevention of Sudden Cardiac Death). J Am Coll Cardiol 2006; 48:e247-346.

33. Fuster V, Rydén LE, Cannom DS, et al. ACC/AHA/ESC 2006 Guidelines for the Management of Patients with Atrial Fibrillation: a report of the American College of Cardiology/American Heart Association Task Force on Practice Guidelines and the European Society of Cardiology Committee for Practice Guidelines (Writing Committee to Revise the 2001 Guidelines for the Management of Patients With Atrial Fibrillation): developed in collaboration with the European Heart Rhythm Association and the Heart Rhythm Society. Circulation 2006;114:e257-354.

34. Kara T, Narkiewicz K, Somers VK. Chemoreflexes--physiology and clinical implications. Acta Physiol Scand 2003;177:377-384.

35. Cooper VL, Pearson SB, Bowker CM, Elliott MW, Hainsworth R. Interaction of chemoreceptor and baroreceptor reflexes by hypoxia and hypercapnia 
- a mechanism for promoting hypertension in obstructive sleep apnoea. J Physiol 2005;568:677-687.

36. Caples SM, Somers VK. Sleep-disordered breathing and atrial fibrillation. Prog Cardiovasc Dis 2009;51:411-415.

37. Chen LY, Shen WK. Epidemiology of atrial fibrillation: a current perspective. Heart Rhythm 2007;4(Suppl 3):S1-6.
38. Jouett NP, Watenpaugh DE, Dunlap ME, Smith ML. Interactive effects of hypoxia, hypercapnia and lung volume on sympathetic nerve activity in humans. Exp Physiol 2015;100:1018-1029.

39. Chen PS, Douglas P, Lecture Z. Neural mechanisms of atrial fibrillation. Heart Rhythm 2006;3:1373-1377.

40. Kanagala R, Murali NS, Friedman PA, et al. Obstructive sleep apnea and the recurrence of atrial fibrillation. Circulation 2003;107:2589-2594. 